IJMS 17 (Special Issue), 85-99 (2010)

\title{
ISLAMIC FINANCE AND ITS CONTRIBUTION TO SOLVING THE CURRENT FINANCIAL CRISIS
}

\author{
MOHAMED SHARIF BASHIR \\ Faculty of Business and Management Sciences \\ Sultan Sharif Ali Islamic University, Brunei Darussalam
}

\begin{abstract}
As a result of the global financial crisis and its effects on the world economy, there is an increasing awareness and exploration of more vigorous frameworks and types of financial tools and intermediations. With its emphasis on asset-backed transactions, Islamic finance can contribute to overcoming the challenges and difficulties created by the current credit crisis. At its core, Islamic finance is concerned with the deployment of capital in genuine commercial activities that will benefit the whole world. So far, the techniques used in Islamic finance, if applied and executed properly, have created a much closer relationship among the customer, the financier, and the asset. In both principle and practice, Islamic finance prohibits the creation of debt through direct lending and borrowing, thus prohibiting excessive leverage, which is a root cause of the financial crisis. This paper highlights the strengths of Islamic finance in the context of the current financial and economic crisis. This paper examines whether Islamic finance could help to provide an alternative approach to the problems that led to the crisis that would prevent the repetition of a similar crisis in the future.
\end{abstract}

Keywords: Islamic finance; Islamic financial system; financial crisis; profitloss sharing; risk management.

JEL Classification Code: G01; G21; G32, Z12.

\section{Introduction}

The present global financial crisis has been described as the most severe since the Great Depression. Experts believe that the situation may get worse if the crisis spreads further and could lead to a failure of financial institutions, corporations, and derivatives agents ${ }^{1}$. It has 
taken more than $\$ 3$ trillion of bailout and liquidity injections by several countries to minimise the serious effects of the crisis (UNDESA, 2008). In addition, there are fears that the crisis may have exposed the world economy to a long period of slowdown. There is, therefore, a need for a new architecture that would help minimise the severity of similar crises in a short period of time.

Attempts have made by a number of policy makers in developed and developing countries to stave off regional and global recessions, and restore stability and confidence in financial markets. For instance, the largest industrial economies are pursuing a massive and unprecedented programme of government intervention by nationalising banks, injecting massive subsidies into ailing institutions, and revising regulations of their financial sectors (Elliott, 2008). These attempts sit in direct contrast to the neo-liberal policies pressed on developing countries by the World Bank and the International Monetary Fund for the past 30 years, which have been perceived as unacceptable from a free market perspective. People are questioning the current international financial system, its architecture, and its institutions, and these issues will need to be regarded in new ways. Unlike the international financial system, Islamic finance has entered a bright new stage of development, emerging after the global financial crisis as a more equitable and efficient alternative to the Western approach to financial services. This paper is organised as follows. The next section analyses a few basic concepts of Islamic finance and highlights its benefits in light of the current global financial crisis. Section 3 attempts to address questions about whether the Islamic financial system could provide an alternative approach to resolve the current economic and financial crisis, and provide viable solutions to help both domestic and international financial institutions to resolve problems that led to the current economic downturn. The last section concludes the paper with policy implications and some useful recommendations.

\section{Basic Concepts of Islamic Finance}

According to DeLorenzo (2008), Islamic finance is the only example of an economic system directly based on the ethical precepts of a major religion, providing not only investment guidelines but also a set of unique investment and financing products. The basic concepts of Islamic banking and finance go back 14 centuries, but the world's first modern Islamic bank did not open until 1975 (Karim, 2005). Moreover, the sector did not really blossom until five years ago when it was buoyed by rising oil prices and the strengthening economies 
of Asia's Muslim countries. Shari'ah law prohibits investing in certain industries that produce non-halal products, such as alcohol, tobacco, pork, and pornography. The Qur'an also forbids usury, and financial transactions should be their structured to rely on income in the form of rents or profits from permissible finance procedures, technically not interest. Sukuk, or Shari'ah-compliant bonds, for instance, are a type of Islamic bond backed by ownership of a tangible asset that produces a financial return (Ismail, 2010). In 2008, the Accounting and Auditing Organisation for Islamic Financial Institutions (AAOIFI, 2008) defined sukuk as "certificates of equal value representing undivided shares in the ownership of tangible assets, usufructs and services or (in the ownership of) the assets of particular projects or special investment activity". A distinguishing feature of a sukuk is that in instances where the certificate represents a debt to the holder, the certificate will not be tradable on the secondary market and instead is held until maturity or sold at par. Sukuk can provide medium to long-term fixed or variable rates of return. Currently, sukuk are seen as an alternative means to mobilising saving and investment from a massive investor base ${ }^{2}$. Another popular instrument is murabahah, or cost-plus financing, which involves the sale of a commodity with an additional amount of profit. A wide range of customer needs, especially in short-term trade transactions, can be met through the murabahah financing mode (Yatim \& Nasir, 2009). It is noteworthy that experts and practitioners of Islamic finance are optimistic about the development of Islamic finance industries while the world struggles financially. More countries are being affected by the global financial crisis, including countries that address both conventional finance and Islamic finance. Currently, some countries are paying more attention to Islamic financial institutions and allowing these institutions to grow (Hawser, 2008; Aziz, 2009a).

A working paper issued by the IMF (2008) indicated that institutions offering Islamic financial services constitute a significant and growing share of the financial system in a number of countries. It emphasised the relative financial strength of Islamic banks and revealed that small Islamic banks tend to be financially stronger than small commercial banks. It also stated that the market share of Islamic banks does not have a significant impact on the financial strength of other banks (Čihák \& Hesse, 2008). Despite the relatively small amount of resources managed by institutions offering Islamic financial services, the direct link of financial resources and real productive activities can help economies to face the rising challenges of the current crisis.

Some financial experts see the current global financial crisis as a big opportunity for Islamic finance as it has the capacity and capability

IJMS 17 (Special Issue), 85-99 (2010) 
to bring stability to the market (Aziz, 2009b). The current global crisis caused colossal financial losses estimated to be in the billions of dollars. It would not have occurred if the Islamic principles regarding collateralised debt obligations were in vogue in the international financial market. For instance, Islamic bonds, which carry unique structural features, cannot create a calamity such as the subprime mortgage crisis. It is the right time for the Islamic banking industry to present solutions to the global economic community in the wake of the current crisis. Chapra (2008a) argued that a crisis, such as the one that occurred in the mortgage industry, would technically be unthinkable in the Islamic capital market sector because it would be against Shari'ah principles to sell a debt against a debt ${ }^{3}$. In the present crisis, it has become obvious that trillions of dollars are traded without any assets backing them. Chapra (2008b) pointed out that "if such transactions followed the Islamic finance model it would have easily prevented the current financial crisis". Other authors also support the idea that Islamic finance can provide an alternative that would prevent a similar crisis from occurring (Ahmed, 2009; Siddiqi, 2009).

\section{Dimensions of Islamic Finance Evolution}

The rapid evolution of the Islamic financial system is particularly evident in the four dimensions of its development. First, today's Islamic finance is viewed as a competitive form of financial intermediation, drawing significant participation by non-Muslims. According to the governor of the Central Bank of Malaysia, the total assets of the Islamic financial system have surpassed $\$ 1$ trillion, a fivefold increase over their magnitude just five years ago. Islamic finance is among the fastest growing financial segments in the world, with an estimated annual growth of 20\% (Aziz, 2009a).

Secondly, with the emergence of more diverse Islamic finance institutions and the development of Islamic finance markets, the scope of the Islamic finance business has expanded to include private equity, project finance, the origination and issuance of Sukuk (Islamic bonds), as well as fund, asset, and wealth management activities (Ismail, 2010).

Thirdly, this dimension in which there has been significant evolution is in the regulatory and legal framework of Islamic finance, which is shaped by the distinct features of Islamic finance transactions. This has ensured that the growth and development of Islamic finance is accompanied by the corresponding development of this framework. Fourthly, the international dimension of Islamic finance has rapidly 
gained significance as it evolves to become an increasingly important part of the international financial system and as it becomes poised to contribute to greater global financial integration. The expansion of the network of links among intermediaries and markets in various regions will contribute to a more efficient allocation of financial resources across borders and thus contribute to enhancing global growth prospects (Chapra, 2008b).

\section{Discipline of the Islamic Financial System}

The Islamic financial system, which introduces greater discipline into the economy and links credit expansion to the growth of the real economy, is capable of minimising the severity and frequency of financial crises. Islamic finance can also reduce the problem of subprime borrowers by providing them with loans at affordable terms. This will save billions of dollars that are spent to bail out the rich bankers. Muslims have a genuine Islamic financial system with proper checks and controls. The Islamic financial system does not allow the creation of debt through direct lending and borrowing. Instead, it requires the creation of debt through the sale or lease of real assets by means of its sales and lease-based modes of financing. The regulatory regimes in the Islamic system require that the asset being sold or leased must be real and not imaginary or notional, and the seller must own and possess the goods being sold or leased. Furthermore, the transaction must be genuine with the buyer and seller fully intending to give and take delivery and the debt cannot be sold, so the risk associated with it cannot be transferred to someone else. The conditions set by the Islamic system would help eliminate most speculative transactions. Financing extended through the Islamic products can expand only in step with the rise of the real economy, and this would help curb excessive credit expansion (Siddiqi, 2009; Chapra, 2008a).

Muslim scholars have emphasised the significance of the condition that prevents a creditor from transferring the risk to someone else by selling the debt. This will help eliminate a great deal of speculative and derivative transactions where there is no intention of giving or taking delivery. It will also help prevent an unnecessary explosion in the volume and value of transactions, and the debt from rising far above the size of the real economy. In addition, it will release a greater volume of financial resources for the real economic sectors and thereby help expand employment and self-employment opportunities, and the production of need-fulfilling goods and services (Hassan \& Kayed, 2009). 
The discipline that Islam wishes to introduce in the financial system may not materialise unless the governments reduce their borrowing from the central bank to a level that is in harmony with the goal of price and financial stability, as excessive and imprudent lending by banks was the main cause of the current global crisis. There are three factors that make this possible. First is the inadequate market discipline in the financial system resulting from the absence of profit-and-loss sharing (PLS). Secondly, there is the mind-boggling expansion in the size of derivatives, particularly credit default swaps (CDSs) (Chapra, 2008a). Finally, there is the "too big to fail" concept that led banks to believe that the central bank would come to their rescue. The false sense of immunity from losses introduces a fault line in the system as banks do not undertake a careful evaluation of their loan projects. This leads to an unhealthy expansion in the overall volume of credit, to excessive leverage, and to an unsustainable rise in asset prices, thus living beyond one's means, and speculative investment. Unwinding later on gives rise to a steep decline in asset prices, and to financial frangibility and debt crisis, particularly if there is overindulgence in short sales (Chapra, 2008b; Rehman, 2009).

\section{Objectives of the Islamic Financial System}

The Islamic finance industry encompasses retail and investment banking, insurance, fund management, and the issuance and trading of securities that comply with Shari'ah (consistent with the principles of Islamic law). Shari'ah prohibits the payment of interest on loans (Riba or usury) as well as investing in businesses that provide goods or services considered contrary to its principles, such as pork, alcohol, = or gambling. Islamic finance has not felt the full brunt of the global credit crisis that has rocked conventional banks. Islamic finance has, thus far, remained positive, despite the current challenging global financial environment. The Shari'ah injunctions require that the financial transactions are accompanied by an underlying productive activity, thus giving rise to a close link between financial and productive flows. Islamic banks are also required to share profits and losses arising from projects, prompting lenders to undertake the necessary checks to ensure that a venture is sound.

The global Islamic finance industry, valued by the Asian Development Bank at US $\$ 1$ trillion, has been regarded by some investors as a safer alternative as the Shari'ah forbids complex, opaque financing structures similar to subprime loans that triggered the U.S. housing collapse. Still, uncertainties in global markets have had an impact on Islamic transactions. While Islamic finance, by its very nature, engages only in 
transactions that have underlying tangible productive activities, the slower overall growth and the increased uncertainties have affected pricing and activity in certain market segments (ADB, 2010).

One of the most important objectives of Islam is to realise greater justice in human society. According to the Qur'an, a society where there is no justice will ultimately head toward decline and destruction (57:25). Justice requires a set of rules or moral values with which everyone agrees and faithfully complies. The financial system may be able to promote justice if, in addition to being strong and stable, it satisfies at least two conditions based on moral values. One of these is that the financier should share in the risk so as not to shift the entire burden of losses to the entrepreneur, and the other is that an equitable share of financial resources mobilised by financial institutions should become available to the poor to help eliminate poverty, expand employment, and self-employment opportunities and thus help reduce inequalities of income and wealth. To fulfil the first condition of justice, Islam requires both the financier and the entrepreneur to equitably share the profit as well as the loss. For this purpose, one of the basic principles of Islamic finance is "no risk, no gain." This should help introduce greater discipline into the financial system by motivating financial institutions to assess the risks more carefully and to effectively monitor the use of funds by the borrowers. The double assessment of risks by both the financier and the entrepreneur should help inject greater discipline into the system and go a long way in reducing excessive lending. Islamic finance should, in its ideal form, help raise the share of equity and PLS. Greater reliance on equity financing has supporters even in mainstream economics. Greater reliance on equity does not necessarily mean that debt financing is ruled out because all the financial needs of individuals, firms, or governments cannot be made amenable to equity and PLS. Debt is, therefore, indispensable but should not be promoted for nonessential and wasteful consumption and unproductive speculation. Therefore, the Islamic financial system does not allow the creation of debt through direct lending and borrowing. Instead, it requires the creation of debt through the sale or lease of real assets by means of its sales-and leasebased modes of financing (Islamic bonds) (Yatim \& Nasir, 2009).

The first condition will help eliminate a large number of derivative transactions that involve nothing more than gambling by third parties who aspire to claim compensation for losses that only the principal party has suffered. The second condition will help ensure that the seller (or lessor) also shares a part of the risk to get a share in the return. Once the seller (financier) acquires ownership and possession of the goods for sale or lease, he/she bears the risk. As Ahmed (2009)

IJMS 17 (Special Issue), 85-99 (2010) 
explained, this condition also puts a constraint on short sales, thereby removing the possibility of a steep decline in asset prices during a downturn. The Shari'ah has, however, made an exception to this rule in the case of salam (sale contract of spot payment for deferred delivery) and istisna (sale contract of staggered payments for deferred delivery) where the goods are not already available on the market and need to be produced or manufactured before delivery (Ismail, 2010). Financing extended through the Islamic modes can expand only in step with the rise of the real economy and thereby help curb excessive credit expansion. The third and the fourth conditions will not only motivate the creditor to be more cautious in evaluating the credit risk but also prevent an unnecessary explosion in the volume and value of transactions. This will prevent the debt from rising far above the size of the real economy and also release a substantial volume of financial resources for the real economy sectors, thereby helping expand employment and self-employment opportunities and the production of goods and services that fulfil needs. The discipline that Islam wishes to introduce in the financial system may not, however, materialise unless governments reduce their borrowing from the central bank to a level that is in harmony with the goal of price and financial stability (Ahmed, 2009).

One may raise an objection here that all these conditions will perhaps end up shrinking the size of the economy by reducing the number and volume of transactions. This is not likely to happen because a number of the speculative and derivative transactions are generally known to be zero-sum games and have rarely contributed positively to total real output. Hence, their decline would also not be likely to hurt the real economy. While a restriction on such transactions will cut the commissions earned by the speculators during an artificially generated boom, it will help them avert losses and bankruptcy that become unavoidable during the decline and lead to a financial crisis. The injection of a greater discipline into the financial system may deprive the subprime borrowers' access to credit. Therefore, justice demands that some suitable innovation be introduced in the system to ensure that even borrowers of small sums are able to get adequate credit. Chapra (2008b) said, "such borrowers are generally considered to be subprime and their inability to get credit will deprive them from realising their dream of owning their own homes and establishing their own micro-enterprises".

The problem here is that Islamic finance is still in its infancy and makes up a very small proportion of international finance. In addition, it does not genuinely reflect the ethos of Islamic teachings. The use of 
equity and PLS is still very small while that of debt-creating modes is preponderant. Moreover, even in the case of debt-creating modes, all the conditions laid down by the Shari'ah are not being faithfully observed as financiers use legal stratagems to escape them. This is partly due to a lack of proper understanding of the ultimate objectives of Islamic finance, the unavailability of trained personnel, and the absence of a number of shared or support institutions that are needed to minimise the risks associated with anonymity, moral hazard, principal/agent conflict of interest, and late settlement of financial obligations. The system is, thus, not fully prepared at present to play a significant role in ensuring the health and stability of the international financial system. It is, however, expected that the system will gradually gain momentum with the passage of time and that it will complement the efforts now being made internationally to promote the health and stability of the global financial system (Chapra, 2008b).

\section{Advantages of Islamic Finance}

Interest in Islamic finance was sparked in the 1970s, and this is mainly attributed to the accumulated petro-dollars in Arab countries. Using a rather pragmatic approach, Westerners thought that respecting Islamic principles regarding finance would attract wealthy Arab investors (Zamir \& Mirakhor, 2007). The second major turning point in Islamic finance took place after the September 11, 2002, attack on the United States. Some leaders declared at that time that Muslims in the Middle East were guilty unless they proved themselves innocent, and as a reaction to this uncertainty and discrimination, Islamic finance disappeared from the West. The amount of capital taken out of the West was over $\$ 200$ billion. Moreover, as the epicenter of global economic growth shifted to Asia, Islamic finance concentrated its focus on these emerging and dynamic markets (Aziz, 2009b). The last, but most critical, stage has already started due to the collapse of the conventional finance system based on interest. Regardless of the religious values associated with Islamic finance, some people sought Islamic finance as a more efficient, equitable, and even sustainable form of finance. Because interest-based transactions are prohibited, Islam encourages business and trade activities that generate fair and legitimate profit. In Islamic finance, there is always a close link between financial flow and productivity. This intrinsic property of Islamic finance contributes to insulating it from the potential risks resulting from excess leverage and speculative financial activities (BNM, 2010). 
Another fundamental principle of Islamic finance is the risk and profit-sharing feature of transactions, such as mudarabah (profit sharing) or musharakah (partnership) contracts (Yatim \& Nasir, 2009). It is this profit and risk-sharing feature of Islamic finance transactions that requires a high level of disclosure and transparency. These disclosures allow the market to assign the appropriate risk premiums to companies, thereby enhancing the potential for market discipline to take effect. These features, which are required by Shari'ah injunctions, provide built-in checks and balances that serve to ensure the financial stability of the Islamic financial system. Because of these features, Islamic finance has experienced major transformations and growth, especially since 2000, and its volume has reached almost $\$ 1.5$ trillion. It has been one of the fastest growing financial markets over the last five years and is expected to continue expanding at an even faster rate (BNM, 2010; Aziz, 2009a).

Many believe the credit crunch will open investors' eyes to the potential of Islamic financing, which continues to be viable and competitive amid the increasingly uncertain global environment and that greater global participation in the development of Islamic finance, both directly and indirectly, would enhance its potential role in contributing to global financial stability. The interest in Islamic financing continues to grow, spurred on by increased attention from conventional banks that are developing greater volumes of Islamic financial products and establishing separate Islamic banking divisions. Despite some highprofile casualties from the credit crunch in the conventional insurance market, the Islamic equivalent continues to grow at a rate of $35 \%$ to $40 \%$ per year, and markets such as Bahrain are attracting some of the big names in Islamic insurance and Islamic re-insurance, including Western firms such as Allianz and the American International Group (AIG) (BNM, 2010; IMF, 2009).

Another advantage that the Islamic financial market has over conventional markets is its relative immaturity in terms of the complexity and sophistication of Shari'ah-compliant financial products. As an example, there remains a high degree of skepticism about the applicability of derivatives under Islamic law. Unlike conventional financial instruments, which tend to be developed in isolation, the need to gain approval from Shari'ah scholars means that Islamic financial products have to jump through a few more hoops before they are deemed suitable for general market distribution. Shari'ah boards constitute a unique form of corporate governance. A group of people is assigned the task of looking at products, not 
just in terms of their marketability. Islamic scholars apply additional checks and balances, which are based not only on the bottom line. It is these checks and balances - and Islamic financing's core principles of no interest, no speculation or uncertainty, and screening out highly leveraged stocks - that could prove to be its biggest appeal. People with a strong leaning toward social responsibility or ethical investments may find Islamic investments more attractive in this climate.

\section{Policy Recommendations}

This discussion and analysis of the crisis has proved that Islamic finance is a credible alternative system that is free of the major weaknesses found in the conventional system. Recently an empirical study compared a sample taken from Malaysia's Shari'ah-compliant stock investment funds with conventional funds during the 2008 financial crisis and demonstrated that the Shari'ah-compliant portfolio was less risky and thus more secure or stable than the conventional one during extremely volatile periods such as the 2008 financial crisis (Wasle \& Premaratne, 2010). A number of Muslim scholars have argued that the strengths of Islamic finance are the consequence of its adherence to ethical rules of finance and socially responsible investments (Ahmed, 2009; Siddiqi, 2009; Seif, 2009). They also contended that if global banking practitioners had adhered to the principles of Islamic finance, which are based on noble ideas of entrepreneurship and transparency, the global crisis would have been prevented. Since the current architecture of the conventional financial system has existed for a long time, it may perhaps be too much to expect the international community to undertake a radical structural reform of the kind that the Islamic financial system envisions (Chapra, 2008b).

In summary, while experts and scholars continue to debate potential solutions, there is a remarkable level of consensus as to three key causes of the financial crisis (Rehman, 2009):

1. excessive lending and borrowing by households, corporations, governments, and funds;

2. opaque financial securities, including mis-rated securitised debt instruments; and

3. failing in governance at both the institutional and systemic levels. 
However, the adoption of some of the elements of the Islamic financial system is vital to solve the current crisis and ensure the stability of the global financial system. The following elements can be specified and identified as policy implications ${ }^{4}$.

- The proportion of equity in total financing needs to be increased, and debt should be reduced. Risk sharing should receive more attention, and collective efforts could promote its concept and implications. This requires decreasing the function of debt finance and increasing the function of equity finance.

Credit needs to be limited primarily to transactions that are related to the real sector in order to ensure that credit expansion moves more or less in step with the growth of the real economy and does not promote destabilising speculation and gambling. In addition, finance should be based on equity rather than debt, and lending transactions should be founded on the concept of asset backing. Therefore, mortgage loans under an alternative system would be backed by a solid asset structure. Leverage needs to be controlled to ensure that credit does not exceed the ability of the borrower to repay.

If the debt instrument, and in particular the collateralised debt obligations (CDOs) are to be sold, there should be full transparency about their quality so that the purchaser knows exactly what he is getting into. It would also be desirable to have the right of recourse for the ultimate purchaser of the CDOs so as to ensure that the lender has the incentive to underwrite the debt carefully.

While there may be no harm in the use of CDOs to provide protection to the lender against default, the swaps should not become instruments used for wagering. Their protective role should be confined to the original lender only and should not cover the other purchasers of swaps who wish to wager on the debtor's default. For this purpose, the derivatives market needs to be properly regulated to remove the element of gambling from it.

- All financial institutions, and not just the commercial banks, need to be properly regulated and supervised so that they remain healthy and do not become a source of systemic risk.

- $\quad$ Some arrangements need to be made to make credit available to subprime borrowers at affordable terms to enable them to buy a home and to establish their own micro-enterprises. This will help save the financial system from crises resulting from widespread defaults by such borrowers. 
- $\quad$ Ethical principles should be introduced in financial reform because ethical perspectives can help shape the financial system during and after a crisis. These ethical principles have roots in universal values rather than the religious laws of any single faith tradition.

- $\quad$ The Islamic finance system can be offered as a framework for a more stable global financial system. The most fundamental principle of Islamic finance is related to interest. Under Islamic finance, making money from money, such as charging interest, is not permitted. Wealth should be made only through legitimate trade and investment in assets. Furthermore, Islamic finance promotes risk sharing based on a profit-and-loss sharing concept as a more equitable means of wealth creation and distribution and to expedite economic maturity and stability. Furthermore, Islamic finance has a built-in risk management mechanism that enables the global financial system to perform in an orderly manner and avoid such crises.

- Finally, the Islamic finance system, which introduces greater discipline into the economy and links credit expansion to the growth of the real economy, is capable of minimising the severity and frequency of financial crises, and it is a viable alternative to the ailing global financial system and serves as a vehicle for recovering from the current global financial crisis.

\section{Endnotes}

1. For a detailed review on the causes of the global financial crisis see Chapra (2008a), Elliott (2008), Hassan and Kayed (2009), Hawser (2008), Reavis (2009), and Rehman (2009).

2. Some risks arising in tradable sukuk can be tackled by wellregulated exchange and legal arrangements. For a detailed discussion see Ahmed (2006 and 2010).

3. Since debt not be traded or sold at discount because it can lead to riba, products like CDOs would not exist in an Islamic financial system. For more discussion see Ahmed and Khan (2007).

4. Some of the suggestions given are derived from Chapra (2008a) and Ahmed (2007). 


\section{References}

Accounting and Auditing Organisation for Islamic Financial Institutions (AAOIFI). (2008). Shariah standards for financial institutions. Manama. Bahrain: AAOIFI.

Ahmed, H. (2009). Financial crisis: Risk and lessons for Islamic finance. ISRA International Journal of Islamic Finance, 1(1), 7-32.

Ahmed, H., \& Khan, T. (2007). Risk management in Islamic banking. In M. K. Hassan, \& K. L Mervyn (Eds.), Handbook of Islamic Banking. Cheltenham: Edward Elgar.

Asian Development Bank. (ADB). (2010). Annual report 2009. Philippines, Manila: ADB.

Aziz, Z. A. (2009a, March 3). Governor's address at the launch of Public Islamic Bank Berhad. Mandarin Oriental Kuala Lumpur: BNM.

Aziz, Z. A. (2009b, October 5). Islamic finance and global financial stability. Governor's Keynote Address at the Seminar on Islamic finance: During and after the global financial crisis. Hilton Convention Centre, Istanbul, Turkey. Quarterly Economic Bulletin, fourth quarter 2009, pp. 136-140: BNM.

Bank Negara Malaysia (BNM). (2010). Annual report 2009. Kuala Lumpur: Government printing department.

Chapra, M. U. (2007, March/April). The case against interest: Is it compelling? Thunderbird International Business Review, 49(2), 161-186.

Chapra, M. U. (2008a, April 19-20). Innovation and authenticity in Islamic finance. A keynote forum lecture delivered at the inaugural session of the Eighth Harvard University Forum on Islamic

Finance in the Harvard Law School. Cambridge, MA.

Chapra, M. U. (2008b). The global financial crisis: Can Islamic finance help minimize the severity and frequency of such a crisis in the future? Forum on the global financial crisis, Islamic Development Bank, Jeddah, Saudi Arabia: IRTI.

Čihák, M., \& Hesse, H. (2008). Islamic banks and financial stability: An empirical analysis. IMF working paper no. 08/16. Washington: International Monetary Fund.

DeLorenzo, S. Y. (2008). Speech at the discussion on Islamic finance and the global economic crisis. Kuala Lumpur, Malaysia: BNM.

Elliott, L. (2008, August 5). Credit crisis - How it all began. The Guardian, p.22. Retrieved from http://www.guardian.co.uk/ business/2008/aug/05/northernrock. banking

Hassan, M. K., \& Kayed, R. N. (2009). The global financial crisis, risk management and social justice in Islamic finance. ISRA International Journal of Islamic Finance, 1(1), 33-58. 
Hawser, A. (2008, December 10). Islamic finance and the current global crisis. Retrieved from http://cambridgeforecast.wordpress.com/ 2008/12/10/islamic-finance-and-the-current-global-crisis/

International Monetary Fund (IMF). (2009, April). World economic outlook: Crisis and recovery. Retrieved from http://www.imf.org/ external/pubs/ft/weo/2009/01/pdf / exesum.pdf

Ismail, A. G. (2010). Money, Islamic banks and the real economy. Singapore: Cengage Learning Asia.

Karim, A. A. (2005). Islamic banking: Figh and financial analysis. (Sukasah Syahadan, trans). Indonesia, Jakrta: PT Rajagrafindo Persada. (Original work published 2001).

Reavis, C. (2009). The global financial crisis of 2008-2009: The role of greed, fear and oligarchs. Retrieved from https://mitsloan. mit.edu/MSTIR/GlobalFinancialCrisis/Crisis-2008-2009/ Documents/09-093\%20The\%20Financial\%20Crisis\%20of\%20 008-2009.Pdf

Rehman, A. A. (2009, March 16). The relevance of Islamic finance principles to the global financial crisis. Discussion paper for Harvard Islamic finance programme, Panel discussion. 1-13.

Seif, T. (2009, February 26). The current financial and economic crisis within the markets: An overview. Paper Presented at the Harvard, London School of Economics. Workshop on Risk Management (Islamic Economics and Islamic Ethico-Legal Perspectives on Current Financial Crisis): London School of Economics.

Siddiqi, M. N. (2009, February 26). Risk management in Islamic framework. Paper presented at the Harvard, London School of Economics. Workshop on Risk Management (Islamic Economics and Islamic Ethico-Legal Perspectives on Current Financial Crisis): London School of Economics.

United Nations Department of Economic and Social Affairs (UNDESA). (2008). Bubbles, busts, and bailouts: Lessons from the global financial meltdown. UN-DESA Policy Brief No. 9, 1-4.

Wasle, R. R., \& Premaratne, G. (2010, March 1-2). Examining the behaviour of a Shariah-compliant portfolio during the 2008 financial crisis. Proceedings of the International Conference on Islamic Finance. Gadong, Brunei: UNISSA, 1-26.

Yatim, M. N., \& Nasir, A. H. (2009). The principles and practice of Islamic banking and finance. Second edition. Kuala Lumpur: Prentice Hall- Pearson Malaysia.

Zamir, I., \& Mirakhor, A. (2007). An introduction to Islamic finance: Theory and practice. Singapore: John Wiley and Sons. 